ELORE (ISSN 1456-3010), vol. $18-1 / 2011$.

Julkaisija: Suomen Kansantietouden Tutkijain Seura ry. [http://www.elore.fi/arkisto/1_11/ajank_hameenaho.pdf]

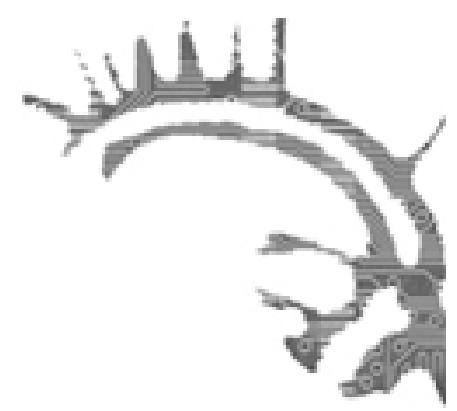

\title{
Ajankohtaista
}

\section{INHIMILLISEN KULTTUURIN REUNAEHTOJA TUTKIMASSA}

\section{$\underline{\text { Pilvi Hämeenaho }}$}

Non-Human in Anthropology. Monitieteinen konferenssi 4.-5.12.2010 Prahassa

Joulukuussa 2010 Prahaan, Kaarlen yliopiston humanistisen tiedekunnan tiloihin, kokoontui joukko antropologeja, sosiologeja ja monien lähitieteiden edustajia keskustelemaan ei-inhimillisten tekijöiden vaikutuksesta inhimilliseen kulttuuriin ja yhteiskunnallisiin ilmiöihin. Lähtökohtana oli avata uusia tutkimuksellisia näkökulmia, joiden kautta voimme tutkia elämäämme kiinteästi vaikuttavia tekijöitä osana kulttuurista kokonaisuutta. Päivien keskeisiksi teemoiksi muodostuivat materiaalisen suhde aikaan ja luonnon oloihin, eläinten ja eläinkulttuurin tutkimus sekä ajallisten ja tilallisten etäisyyksien vaikutukset ihmisten arkeen.

Yksi keskeinen tekijä kulttuurimme muodostumiselle on se fyysinen ympäristö, jossa toimimme. Luonto itse otti merkittävällä tavaa osaa konferenssin kulkuun: joulukuun alun Praha, kuten muukin Keski-Eurooppa, taisteli lumimyrskyjen kourissa, ja useat konferenssin osallistujat joutuivat perumaan tulonsa sään takia peruutettujen lentojen vuoksi. Keski-Euroopalle poikkeuksellisen talvinen sää, ei ihmisen luomana, mutta vahvasti arkiseen toimintaamme liittyvänä tekijänä, loi mielenkiintoisen kehyksen päiville. Suomalaisena kulttuurien tutkijana oli mielenkiintoista havaita, että sää toimii small talkin aiheena muuallakin kuin Suomessa - kunhan siinä vain on jotain riittävän erikoista.

\section{MONITIETEINEN KESKUSTELUFOORUMI}

Kaarlen yliopiston humanistisen tiedekunnan entinen dekaani, Tsekin kulttuuriminis- 
terinäkin toiminut filosofi Jan Sokol, toivotti konferenssivieraat tervetulleiksi muistuttamalla inhimillisen kulttuurin ja luonnon ikuisesta vuorovaikutuksesta. Luontoa, materiaalista ympäristöämme ja eläimiä koskeva tutkimus ei ole vain luonnontieteiden velvollisuus, vaan niiden merkitys inhimilliselle kulttuurille haastaa myös humanistit ja sosiaalitieteilijät mukaan tutkimukseen. Konferenssi kokosi paikalle laajan kirjon tutkijoita eri aloilta, ja esitelmiä pitivät esimerkiksi sosiaali- ja kulttuuriantropologit, sosiologit, etnologit, folkloristit, ympäristötieteilijät, historioitsijat ja filosofian tutkijat. Vain yhden viikonlopun kestänyt konferenssi toi paikalle noin 50 henkeä Euroopasta, Venäjältä sekä Yhdysvalloista. Monet kertoivat osallistuneensa hyvinkin pitkälti uteliaisuudesta, haluten tietää mitä kaikkea käsitteen "Non-Human" taakse voikaan kätkeytyä. Suurin osa esitelmistä perustui puhujien väitöskirjoihin tai post doc -tutkimuksiin.

Konferenssin esitelmät oli jaettu kolmeen ryhmään: eläimet ja hybridit, materiaalinen kulttuuri sekä ajan ja tilan tutkimus. Esitelmien aiheet liikkuivat kuitenkin temaattisen jaottelun rajojen yli, ja moni paperi olisi sopinut useamman yläotsikon alle. Esitelmät oli myös aikataulutettu siten, että kaikilla oli mahdollisuus kuunnella muitakin kuin oman työryhmänsä esitelmiä. Tämä teki päivien sisällön erittäin mielenkiintoiseksi ja vaihtelevaksi avaten varmasti jokaiselle paikalla olleelle uusia näkökulmia omaan tutkimukseen ja sen kysymyksenasetteluihin. Liian tarkasti etukäteen annetuissa teemoissa ei yritettykään pysyä, ja etenkin esitelmien välillä käyty keskustelu yhdisteli aiheita työryhmärajojen yli.

\section{MATERIAALINEN PYSYVyYs Ja MUUTTUUUUS}

Materiaalisen kulttuurin johdantoluennon, ja koko konferenssin avausluennon, piti antropologi ja arkkitehti Victor Buchli (College University of London). Hän pohti esineiden ja materiaalisen ympäristömme muutosta ja pysyvyyttä erityisesti modernin teknologian tuomien mahdollisuuksien kautta. Teknologinen kehitys nostaa esiin immateriaalisen ja materiaalisen suhteen - sarjatuotannon kautta valmistuvan esineen kannalta ainoa tarvittava tieto voi löytyä koodista, nollista ja ykkösistä, joiden avulla valmistamiseen tarvittava kaava - ja siten lopputuloksena saatava esine, on toistettavissa lukemattomia kertoja. Buchli nostikin esiin kulttuurisen säilyttämisen kysymyksen: Onko binääri-koodiin perustuvalla menetelmällä valmistettu esine se kulttuurinen tuote, joka säilytetään, vai tulisiko esimerkiksi museoon tallentaa alkuperäinen koodi? Materiaalinen todellisuutemme on tietoteknisen kehityksen kautta muutoksessa, jossa esine itsessään ei ole ainutkertainen, vaan muuttuva ja katoava, mutta tieto sen toistamiseksi lukemattomia kertoja voidaan tallentaa pysyvästi. Esimerkki myös kyseenalaisti käsityksemme ohjelmoinnin tuotteena syntyvien koodien immateriaalisuudesta tuoden esiin niiden merkityksen materiaalisen ympäristön luomisessa ja säilyttämisessä.

Toisen konferenssipäivän avasi Tim Edensor (Manchester Metropolitan University). Esitelmässään hän pohti ajan ja ympäristön suhdetta kuvailemalla Manchesterilaisen St Ann's -kirkon rakennuskivien historiaa - sekä fyysisiä muutoksia että niitä kulttuurisia merkityksiä, joita kirkon ajan kuluessa muuttunut ulkoasu on ihmisten mielissä saanut. 
Esitelmä korosti materiaalisen todellisuuden jatkuvaa muutosta näyttämällä kuinka "pysyvänä" ja kestävänä ajattelemamme kivi elää ja muuttuu, toisaalta vuosisatojen kuluessa, toisaalta hyvinkin nopeasti. Nämä muutokset näkyvät kirkon muuttuvana ulkonäkönä ja vaikuttavat myös kokemukseen kirkon visuaalisesti hallitsemasta tilasta. Aikojen kuluessa kirkon ulkonäköön ovat vaikuttaneet sään ja materiaalien vanhenemisesta aiheutuva eroosio sekä ihmisten tekemät, lähinnä korjaavat, muutokset. Esitelmä näytti kiven alituisessa muutoksessa olevana materiaalina, vastaparinaan inhimillinen mielikuvien, arvojen ja tyylitajun pysyvyys. Kaupungin asukkaiden ja kirkossa kävijöiden mielikuvat ja rakennuksen ulkonäköön liittyvät toiveet edustavat pysyvämpää ja hitaammin muuttuvaa kulttuuria.

\section{IHMISEN JA LUONNON VUOROVAIKUTUKSESTA}

Päivien aikana kuullut esitelmät käsittelivät laajasti konferenssin teemoihin liittyviä aiheita. Eläimiä sekä luonnon ja ihmisen toiminnan vuorovaikutuksessa syntyviä hybridejä tarkastellut työryhmä nosti esiin tutkimusaiheita, jotka usein liitetään luonnontieteellisen keskustelun piiriin. Kulttuuriimme vaikuttavina toimijoina mainittiin muun muassa bakteerit, hyönteiset, eläimet sekä erityisesti jatkuvasti itseään tutkiva ihminen. Työryhmässä pohdittiin myös ihmisen pyrkimystä hallita ja manipuloida luontoa esimerkiksi jalostamalla kasveja ja eläimiä sekä rakentamalla virtuaalimaailmoja niin sanotun reaalitodellisuuden rinnalle. Esitelmät avasivat eri tieteenaloilla tehtävän tutkimuksen kautta näkökulmia luonnon ja ihmisen väliseen vuorovaikutukseen.

Kun tutkimuskohteena ovat maailmanlaajuisesti leviävät epidemiat (kuten Suomessakin riehunut $\mathrm{H} 1 \mathrm{~N} 1$-virus) tuo antropologinen tutkimus esiin niiden merkitykset, ei vain läk̈ketieteellisinä kysymyksinä, vaan myös yhteiskuntaan ja ihmisten arjen toimintaan vaikuttavina globaali-ilmiöinä. Käytännön tekojen lisäksi epidemiat luovat pelon ja epäluottamuksen tunteita, joita nopeasti medioissa leviävä tieto lisää ja ruokkii. Eläinkokeista käytävää tieteellistä argumentaatiota voidaan tulkita diskurssina, jolloin eläinten esineellistämisen logiikka tulee näkyville. Tutkimuseettiset kysymykset eläinkokeiden julmuudesta tai niiden aiheuttamasta kärsimyksestä katoavat, kun koeeläin nähdään esineenä, vain yhtenä objektina muiden laboratoriovälineiden joukossa.

Paikkaa ja tilallisuutta käsittelevän työryhmän aiheita olivat esimerkiksi muuttuvat kaupunkitilat, välimatkat ja etäisyydet arjen kulkuun vaikuttavina tekijöinä sekä rakennusten ja luontokohteiden merkitysten muutokset ajassa ja tilassa. Niin sanottuja brownfield-alueita tarkasteltiin useammassa esitelmässä, sekä maisemaekologian että arkkitehtuurin ja kaupunkisuunnittelun näkökulmista. Brownfield-alueet ovat esimerkiksi teollisuudelta käyttämättömäksi jääneitä laajoja aloja, joista rakennukset on purettu pois. Jättömaista on mahdollista, kun rahaa ja poliittista tahtoa löytyy, rakentaa asuinalueita, puistoja ja toimintakeskuksia kansalaisten käyttöön, kuten esimerkiksi Budapestiin entisen kemiantehtaan paikalle rakennettu "Millenium Park". Haasteita uudelleen käytölle aiheuttaa erityisesti saastunut maaperä, jonka vuoksi puhdistuksenkaan jälkeen kaikille alueille ei voida rakentaa asuintaloja. Alueet voidaan nähdä sekä ongelmina että mahdollisuuksina uudelle kaupunkisuunnittelulle. Monet alueista ovat tällä hetkellä vailla mitään virallista käyttöä ja ne muodostavat mielenkiintoisen 
yhdistelmän urbaania ihmisen rakentamaa ympäristöä ja vuosien käyttämättömyydestä aiheutunutta luonnontilaistumista.

Visuaalisesti hahmotettavan maiseman lisäksi huomiota sai urbaani äänimaisema etnologisena tutkimuskohteena. Esitelmä Berliinin äänimaisemasta ja erityisesti liikenteen muodostamasta taustahälystä (drone) avasi ääninäytteiden avulla monesta maasta tulleiden kuulijoiden korvat pohtimaan, kuinka samankaltaisia kaupungit ovat kuunneltuina. Toisaalta tämä tietty, ensisijaisesti autojen moottorien jyrinästä muodostuva äänimaailma on käymässä uhanalaiseksi nykypäivän uuden, hiljaisuutta ja äänettömyyttä hakevan autoteollisuuden, hybridimoottorien ja uusien tiepinnoitteiden aikakaudella.

Työryhmä toi esiin tärkeinä näkökulmina pitkät välimatkat ja niiden vaikutukset ihmisten arkeen. Pitkien välimatkojen tuomat haasteet yhdistyivät materiaalisen kulttuurin tutkimukseen kausityöläisten arkea kuvanneen tutkimuksen kautta. Ukrainalaisten, Tshekeissä lastenhoitajina kausityöläisinä työskentelevien äitien suhde kotona Ukrainassa odottaviin lapsiinsa rakentuu esineiden ostamisen ja lahjaksi lähettämisen kautta. Koska äidit eivät näe lapsiaan jopa puoleen vuoteen, ovat kotiin lähetettävät tavarat ja vaatteet ainoa keino osoittaa rakkautta lapsia kohtaan. Nämä "rakkauden lahjat" (gifts of love) toimivat tunteiden välittämisen siltoina maantieteellisesti erossa olevien perheen jäsenten kesken. Oma, maaseudun päivittäistä autoilua käsittelevä esitelmäni liittyi kiinteästi luontoon ja sääoloihin sekä niiden vaikutuksiin ihmisten arjen sujuvuudelle. Suomalaisen talven muodostamat elämisen reunaehdot ja maaseudun pitkät välimatkat näyttäytyivät eksoottisena arjen ympäristönä verrattuna tiheästi asutettuun Keski-Eurooppaan.

\section{ILLANVIETTOA JA VERKOSTOITUMISTA}

Ensimmäisen konferenssi-päivän jälkeen kaikki halukkaat olivat tervetulleita osallistumaan "uusi urbaani erämaa" (new urban wilderness) -kävelyretkelle, joka suuntautui Prahan keskustassa sijaitsevalle jättömaalle. Kylmä sää, pimeys ja polviin asti ulottuvat kinokset karsivat halukkaita kävelijöitä, koska harva oli varautunut vaellukseen lumierämaassa. Kohde oli kuitenkin poikkeuksellisen kiinnostava, vuoden 2002 tulvissa infrastruktuuriltaan tuhoutunut Rohanin saari (Robanský ostrov), joka on tällä hetkellä tyhjä, metsittynyt ja paikoitellen täynnä tuhon jäljiltä jäänyttä rakennusromua. Ohikulkijoiden ja puistokemistien vapaana ulkoilualueena toimiva alue on tarjonnut tilan spontaanille ympäristötaiteelle, ja kesällä saarella on nähty niin jalkapallotreenejä kuin auringonottajiakin. Pimeänä talvi-iltana ainoa näkyvä toiminta oli kuitenkin kansainvälisen tutkijaryhmän kävelyretki, joka näkyi ja kuului paikan "vakituisille" asukkaille lähinnä salamavalojen räiskyntänä ja naurunremakkana.

Lauantai-iltana tarjolla oli myös tshekkiläinen iltapala paikallisessa ravintolassa, jossa tarjolla oli jo päivän lounaalta tutuksi tulleita majoneesileipiä sekä leikkeleitä, makkaraa, suolakurkkuja ja monenlaista salaattia. Paikalliseen ruokakulttuuriin perehtymisen yhteydessä kaikilla oli mahdollisuus tutustua myös toisiinsa esitelmäpäivää paremmin sekä keskustella ensimmäisen päivän tieteellisestä annista. Koska ryhmä oli verrattain pieni, ihmisiin ehti oikeasti tutustuakin kaksipäiväisen konferenssin tiukasta aikataulusta huolimatta. 
Päivien aikana tuli erittäin selväksi, että monien tutkimusaiheet ovat hyvinkin vahvasti sitoutuneita juuri elämämme ei-inhimillisiin tekijöihin, joihin sopeutuminen, joiden kanssa eläminen ja joiden ohjailu ja muokkaus muodostavat keskeisen osan sosiaalista ja kulttuurista toimintaamme. Konferenssi järjestetään uudestaan syksyllä 2011, ja vuoden 2010 esitelmien pohjalta tullaan julkaisemaan artikkelikokoelma. Tiedotusta tulevista Non-Human in Anthropology -tapahtumista kannattaa seurata esimerkiksi Kaarlen yliopiston humanistisen tiedekunnan internet-sivuilta. Etnologina koin olevani hyvinkin kotonani tässä monitieteisessä ryhmässä.

Filosofian maisteri Pilvi Hämeenaho valmistelee etnologian alan väitöskirjaansa Jyväskylän yliopistossa, historian ja etnologian laitokselle. 